\title{
Performance Evaluation of Spark Ignited Engine Fueled with Gasoline-Ethanol-Methanol Blends
}

\author{
Mohammed Kamil ${ }^{1}$ and Ibrahim Thamer Nazzal ${ }^{2}$ \\ 1. Mechanical Engineering Department, University of Sharjah, Sharjah 27272, UAE \\ 2. Mechanical Engineering Department, Graduate School of Engineering, Özyeğin University, Istanbul 0090, Turkey
}

Received: April 15, 2016 / Accepted: April 25, 2016 / Published: June 30, 2016.

\begin{abstract}
In this paper, experimental investigations are presented to assess the performance variations in a single cylinder spark ignited engine when run with three different gasoline-alcohol blends: (88\% gasoline-12\% methanol, $88 \%$ gasoline- $12 \%$ ethanol and $88 \%$ gasoline- $6 \%$ methanol-6\% ethanol). Additional tests are carried out with the basic gasoline fuel for comparison analysis and performance assessment. Engine performance is investigated under a variety of engine operating conditions. The results are presented in the domain of engine speed. In particular, the brake power of the engine is shown to be slightly increased. The brake thermal efficiency showed an increase compared with the basic gasoline engine. Similarly, it is shown that brake specific fuel consumption is enhanced compared with basic gasoline engine. The exhaust gas temperature showed a decrease compared with gasoline fuel which is preferable to reduce emissions. The alcohol additives are strongly recommended to enhance performance, increasing the mileage and reducing the emissions.
\end{abstract}

Key words: Gasoline, performance, ethanol, methanol, SI engine, blends.

\section{Introduction}

In the modern world, hydrocarbon and fossil fuels (like gasoline and diesel fuels) represent the energy source of the overwhelming majority of internal combustion engines. However, the present reliance on energy from fossil fuels produces unwanted side effects. These effects include environmental pollution which threatens human health, carbon dioxide emissions which accelerate global warming, and geo-political tensions arising from the non-uniform distribution of fossil resources throughout the world [1]. One source of the harmful influnces on the environment of the gasoline fuel is the additivities of the gasoline fuels. These additivities are added mainly to enhance the ON (octane number) since gasoline has low $\mathrm{ON}$ and low resistance to the auto-ignitin combustion abnomality. The fuel makers and petrochemical refineries produced

Corresponding author: Mohammed Kamil, Ph.D., assistant professor, research field: internal combustion engines. several compounds to boost the $\mathrm{ON}$ of gasoline. However, succesive studies and discoveries have shown their environmental problems. TEL (tetra ethyl lead) was the first proposed additive togasoline as an octane booster where 1 gram is added for each one gallon of gasoline. This would increase the $\mathrm{ON}$ of gasoline by 10 degrees [2]. But TEL compounds are toxic and air pollutants, and harm catalytic converter catalysts [3]. Therefore, the fuel makers came up with aromatics compounds (such as benzene and toluene) as new additives. The aromatics produce higher level of smoke and smog, and they are classified as carcinogenic compounds [4]. Moreover, aromatics can cause substantial ozone depletion [5]. Then, MTBE (methyl tertiary butyl ether) was proposed as a new additive with big enthusiasm because of its slow sensitivity to water and its tendency to increase fuel volatility [6]. However, it was discovered later that, MTBE is a big contaminate for the groundwater and a source of serious healthy problems for the human body [7]. 
Alcohol has been used as a fuel throughout history. Alcohol basic fuels (with the chemical formula $\mathrm{C}_{n} \mathrm{H}_{2 n+1} \mathrm{OH}$ ) are interested in for several reasons, but primarily because they are easily produced and can be delivered and utilized much like conventional fossil fuels. The major drawback to their implementation is that they still produce greenhouse gases when burned, thought not at the same levels as traditional fuels [8]. There are four alcohols primarily considered for fuel: methanol, ethanol, propanol and butanol. Methanol and ethanol are both relatively simple to produce and can both be created from carbon dioxide, which could reduce their net contribution to greenhouse emissions. Any of these fuels are listed as biofuels if they are produced from feedstocks. There are some concerns that relying on biofuels will lead to increasing food prices. One advantage shared by all four alcohols is their high octane rating. This tends to increase fuel efficiency and largely offsets the lower energy density of alcohol fuels (as compared to petrol/gasoline and diesel fuels), thus resulting in comparable "fuel economy" in terms of distance per volume metrics, such as kilometers per liter, or miles per gallon. Biobutanol has the advantage that its energy density is closer to gasoline than the simpler alcohols (while still retaining over $25 \%$ higher octane rating); however, biobutanol is currently more difficult to produce than ethanol or methanol [9].

Methanol and ethanol can both be derived from fossil fuels, biomass, or perhaps most simply, from carbon dioxide and water. Ethanol has most commonly been produced through fermentation of sugars, and methanol has most commonly been produced from synthesis gas, but there are more modern ways to obtain these fuels. Enzymes can be used instead of fermentation. Methanol is the simpler molecule, and ethanol can be made from methanol. Methanol can be produced industrially from nearly any biomass, including animal waste, or fromcarbon dioxide and water or steam by first converting the biomass to synthesis gas in a gasifier. It can also be produced in a laboratory using electrolysis or enzymes [10].

Several studies have been exploited to investigate the influence of methanol and ethanol on the performance of gasoline fueled spark ignition engines [9-26]. Ashraf [9] investigated the performance and exhaust emissions from spark-ignition engine fueled with ethanol-methanol-gasoline blends. His test results were obtained with the use of low content rates of ethanol-methanol blends (3-10 vol.\%) in gasoline were compared to ethanol-gasoline blends, methanol-gasoline blends and pure gasoline test results. As for the performance part, he came up with results that methanol-gasoline blends present the highest volumetric efficiency and torque, while ethanol-gasoline blends showed the highest brake power. Alvydas et al. [27] examined the response of the characteristics of the internal combustion engines to the variations in the composition of gasoline-ethanol blends. In their study, they reported a drop in the calorific value (heating value) of the fuel when ethanol is added, whereas the $\mathrm{ON}$ of the resulted beld was increased. They also reported a slight increase in the SFC (specific fuel consumption) and the engine power for the ethanol-gasoline blend. Al-Hasan et al. [17] traced the performance variations for a four strokes sprk inginition enigne fueled with ethanol-unleaded gasoline blends. According to their findings, a drop was observed in the optimium AFR (air fuel ration) and the BSFC (brake specific fuel consumption). However, an increase was traced in the volumetric and brake thermal efficiencies. They reached at the result that 20 vol.\% of ethanol gives the most attractive performace for the considered engine speed range. Similar experimental analysis to investigate the influence of methanol addition to gasoline in spark ignited engines was conducted by Abu et al. [28]. Similar findings were reported as well, the performance of the engine was increased. The ON was also increased and let to the possibility of running the engine with higher compression ratios. These findings were recorded at narrow range of engine speeds $(1,000-2,500 \mathrm{rpm})$. Not 
far from the methodology used in Ref. [28], Mallikarjun and Venkata [29] followed similar methodology to conduct their analysis. They checked the response of a multi cylinder spark ignited engine and its emissions after adding methanol fractions by a ratio ranges from 0 to $15 \%$. Again, similar findings were reported like increasing in the $\mathrm{ON}$, thermal efficiencies. In addition, the knocking problem was shifted away with this blend.

In this paper, experimental investigations are presented to assess the performance variations in a single cylinder spark ignited engine when run with three different gasoline-alcohol blends: $88 \%$ gasoline-12\% methanol, $88 \%$ gasoline-12\% ethanol and $88 \%$ gasoline-6\% methanol-6\% ethanol). Additional tests are carried out with the basic gasoline fuel for comparison analysis and performance assessment.

\section{Experimental Setup and Performance Evaluation}

\subsection{Fuel Preparation}

The final destination of this work is to assess the performance response of the internal combustion engine to the ethanol and methanol fuel additives. To that end, small portions of ethanol and ethanol have been added to facilitate using the same engine systems without major corrections and to avoid the corrosion commonly accompanies these additives. The properties of the pure gasoline, ethanol and methanol fuels are listed in Table 1 [3, 30]. The 88\% gasoline-6\% methanol-6\% ethanol blend was prepared first. Then the two other blends $88 \%$ gasoline- $12 \%$ methanol and $88 \%$ gasoline- $12 \%$ ethanol were prepared. The properties of the selected blends are listed in Table 2. The rating of the RON (research octane number) was conducted using the ASTM-CFR (cooperative fuel research engine) in heat engine laboratory. The ASTM-CFR engine has variable compression ratios.

\subsection{Experimental Setup}

The experimental setup is shown in Fig. 1. It is composed from a single cylinder spark ignited engine with a displacement of $230 \mathrm{cc}$ and a constant compression ratio of 6:1. The bore and stroke are 66 $\mathrm{mm}$ and $57 \mathrm{~mm}$, respectively. This engine is air cooled and naturally aspirated engine with a rated power of 3.5 $\mathrm{kW}$ at 3,600 rpm. A hydraulic dynamometer integrated with full instrumentations for assessing the performance was connected to the engine to load the engine and measure the produced torque. The breathed air by the engine was measured using the air consumption box viscous flow meter. The fuel specific consumption was determined by measuring the time taken for the engine consume given volume for fuel. The fuel flow rate itself was measured by using stop watch and calibrated glass tube. Exhaust gas temperatures were measured using $\mathrm{Ni}-\mathrm{Cr} / \mathrm{Ni}-\mathrm{Al}$ thermocouples. A tachometer with arrange of $150-4,000 \mathrm{rpm}$ was utilized to measure engine speed.

Table 1 Gasoline, ethanol and methanol properties.

\begin{tabular}{llll}
\hline & Methanol & Ethanol & Gasoline \\
\hline Molecular formula & $\mathrm{CH}_{3} \mathrm{OH}$ & $\mathrm{C}_{2} \mathrm{H}_{5} \mathrm{OH}$ & $\mathrm{C}_{4}-\mathrm{C}_{12}$ \\
Molecular weight & 32 & 46 & $95-120$ \\
Oxygen content $(\%)$ & $50 \%$ & $34.8 \%$ & 0 \\
Density $\left(\mathrm{kg} / \mathrm{m}^{3}\right)$ & 792 & 785 & 740 \\
$\mathrm{LHV}(\mathrm{MJ} / \mathrm{kg})$ & 20.0 & 26.9 & 44.3 \\
Octane number & 111 & 108 & $>90$ \\
Auto-ignition temp. $\left({ }^{\circ} \mathrm{C}\right)$ & 465 & 425 & $228-470$ \\
Stoichiometric A/F ratio & 6.47 & 9.00 & 14.8 \\
Latent heat of vapor. $(\mathrm{kJ} / \mathrm{kg})$ & 1,103 & 840 & 305 \\
Boiling point $\left({ }^{\circ} \mathrm{C}\right)$ & 64 & 78 & $38-204$ \\
\hline
\end{tabular}


Table 2 The properties of fuel blends.

\begin{tabular}{llll}
\hline Properties & $\begin{array}{l}88 \% \text { gasoline-6\% } \\
\text { methanol-6\% ethanol }\end{array}$ & $88 \%$ gasoline-12\% methanol & $88 \%$ gasoline-12\% ethanol \\
\hline Specific gravity @ 15.6 & 0.7598 & 0.7612 & 0.7534 \\
RVP (PSI) & 8.1 & 9.6 & 7.1 \\
I.B.P $\left({ }^{\circ} \mathrm{C}\right)$ & 45 & 44 & 46 \\
E.B.P $\left({ }^{\circ} \mathrm{C}\right)$ & 194 & 193 & 195 \\
T.D & 97 & 98 & 97 \\
Loss $(\%)$ & 1 & 1 & 1 \\
Ress. & 1.5 & 1 & 2 \\
Light naphtha & 30 & 30 & 30 \\
Reformate & 70 & 70 & 70 \\
Ethanol & 6 & 0 & 12 \\
Methanol & 6 & 12 & 0 \\
Aromatics & 38.6 & 36.7 & 42 \\
Saturates & 50 & 55 & 44 \\
Research octane number & 87 & 90 & 85 \\
\hline
\end{tabular}

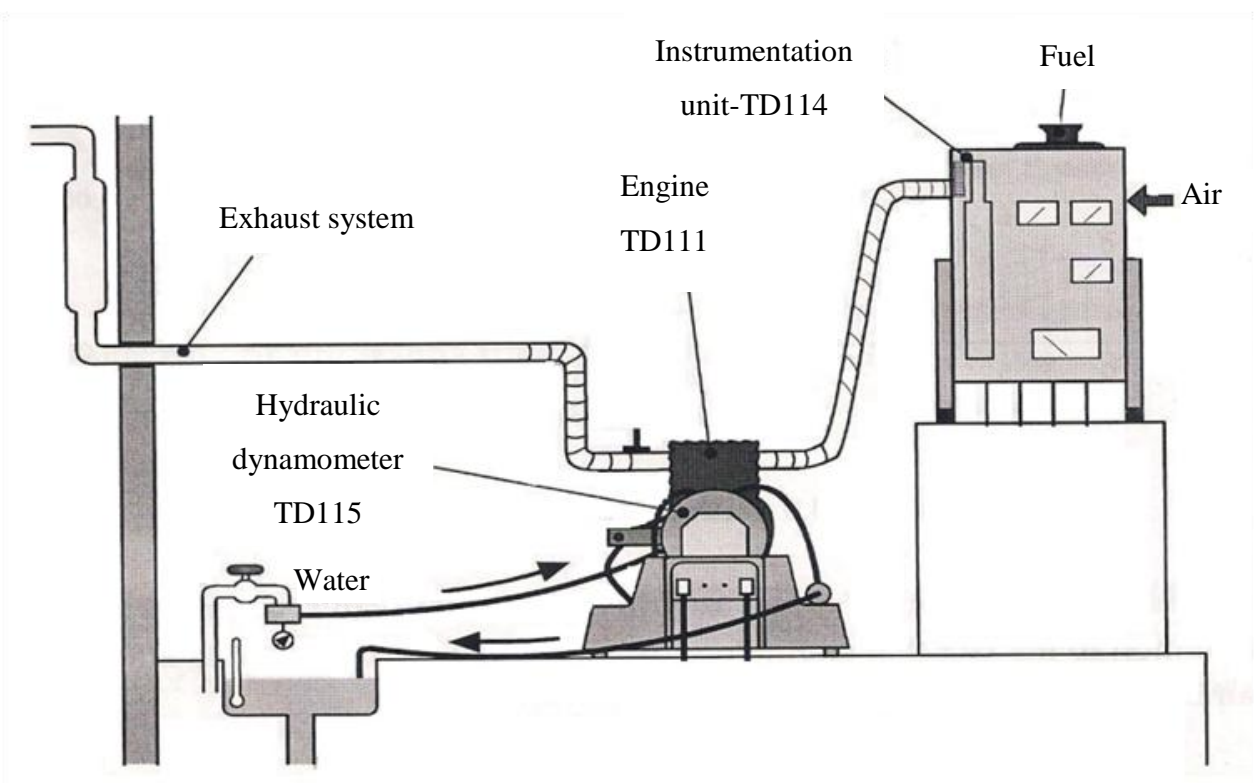

Fig. 1 Schematic diagram of the experimental setup.

\subsection{Experimental Procedure}

The surrounding air conditions were almost maintained unchanged during all the tests by conducting the experiments at similar ambient conditions such as relative humidity and temperature. A warming up period was given to attain the steady state operation temperature. This is of substantial importance because the air cooled engine may have various heat exchanging trends which ultimately influence the performance. A wide open throttle condition was maintained for all the tests, while engine speed was varied from $750 \mathrm{rpm}$ to $300 \mathrm{rpm}$ to assess engine performance. The measurements were repeated five times for each test to assure the repeatability of the readings. Eventually, the mean values were considered. Gasoline fuel was tested first as being the basic fuel for comparison. Then, the selected fuels were examined following the same procedure. Before running the engine with any new fuel, it was allowed to run for a sufficient time to assure consuming all the remaining fuel from the preceding test. 


\subsection{Engine Performance}

Engine performance was assessed considering engine performance parameters which are based on a complete cycle. These parameters include brake power $B_{P}$, brake specific fuel consumption $B S F C$ and thermal brake efficiency $\eta_{B, t h}$. The following expressions were used:

$$
\begin{gathered}
B_{P}=2 \pi N T \\
B S F C=\dot{m}_{f} / B_{P} \\
\eta_{B, t h}=B_{P} /\left(\dot{m}_{f} \times Q_{H V} \times \eta_{C}\right)
\end{gathered}
$$

where, $T$ is the torque, $\dot{m}_{f}$ is the fuel mass flow rate and $\eta_{C}$ is the combustion efficiency (assumed as 98\%).

\section{Results and Discussion}

The engine performance including the $B_{P}, B S F C$ and $\eta_{B, t h}$ at using neat gasoline, gasoline-ethanol blends, gasoline-methanol blends, and gasoline-ethanol-methanol blends at different engine speeds are presented in this section. The $\mathrm{ON}$ of gasoline-methanol and gasoline-ethanol blends was higher compared with neat gasoline fuel. The added portions of the alcohol fuels were expressed as volume percentage to quantify the effect of response in engine performance because of these additives. Figs. 2-5 depict engine performance parameters as obtained from the experimental test considering the above stated fixed conditions.

Fig. 2 shows the effect of engine speed on the brake $B_{p}$ at full load i.e. WOT (wide open throttle). Brake power is the product of the indicated power with the mechanical efficiency. The peak value of the break power is not shown here and it is expected to be at 4,000 rpm. All the considered fuels showed increasing trends of the brake power with engine speed. At 2,000 rpm and compared with the neat gasoline fuel, the operations with the $88 \%$ gasoline- $6 \%$ methanol-6\% ethanol, $88 \%$ gasoline-12\% methanol and 88\% gasoline- $12 \%$ ethanol blends showed an increase in brake power of $23 \%, 27 \%$ and $21 \%$, respectively. For all the considered speed range, the maximum increase in the brake power of $27 \%$ was recorded with the addition of $12 \%$ methanol compared to the engine run by the basic gasoline fuel. However, a similar addition of ethanol would result in an increase of $21 \%$ compared with the basic engine. These trends can be attributed to the properties of methanol. Methanol has the lowest ignition energy compared with the other fuels. In other words, methanol will ignite much less readily compared with the basic fuel. This sounds up the effect of methanol addition on the power obtained from the engine. Then, since the methanol blend has higher ON, this is reflected in more efficient conversion of combustion energy to power.

The BSFC response with engine speed is depicted in Fig. 3 for the considered fuels. Lower SFC is main aspect in the design. BSFC is decreased as engine speed is raised as expected. This behavior is continuing until 2,400 rpm where the trends are inversed and an increase can be seen with engine speed. This is true for all the considered fuels. Average savings in fuel consumption of $10 \%, 14 \%$ and $18.4 \%$ were recorded for the $88 \%$ gasoline- $6 \%$ methanol- $6 \%$ ethanol, $88 \%$ gasoline-12\% methanol and $88 \%$ gasoline- $12 \%$ ethanol blends respectively compared with the basic fuel. This reduction in fuel consumption is due to the presence of the oxygenates which facilitate complete combustion.

In Fig. 4, the brake thermal efficiency is plotted in the engine speed domain for the considered fuels. The best brake thermal efficiency is near the highest load point and drops as the load level decreases by reducing fueling. Thermal efficiency is work-out divided by energy-in. In this case, the energy-in is the product of the mass of fuel and fuel lower heating value. At 2,000 rpm and compared with the neat gasoline fuel, the operations with the $88 \%$ gasoline-6\% methanol- $6 \%$ ethanol, $88 \%$ gasoline-12\% methanol and $88 \%$ gasoline-12\% ethanol blends showed increases in brake power of $23 \%, 32 \%$ and $17 \%$, respectively. For all the considered speed range, the maximum increase in the brake thermal efficiency of $32 \%$ was recorded with the addition of $12 \%$ methanol compared to the engine run by the base gasoline fuel. However, compared to the 


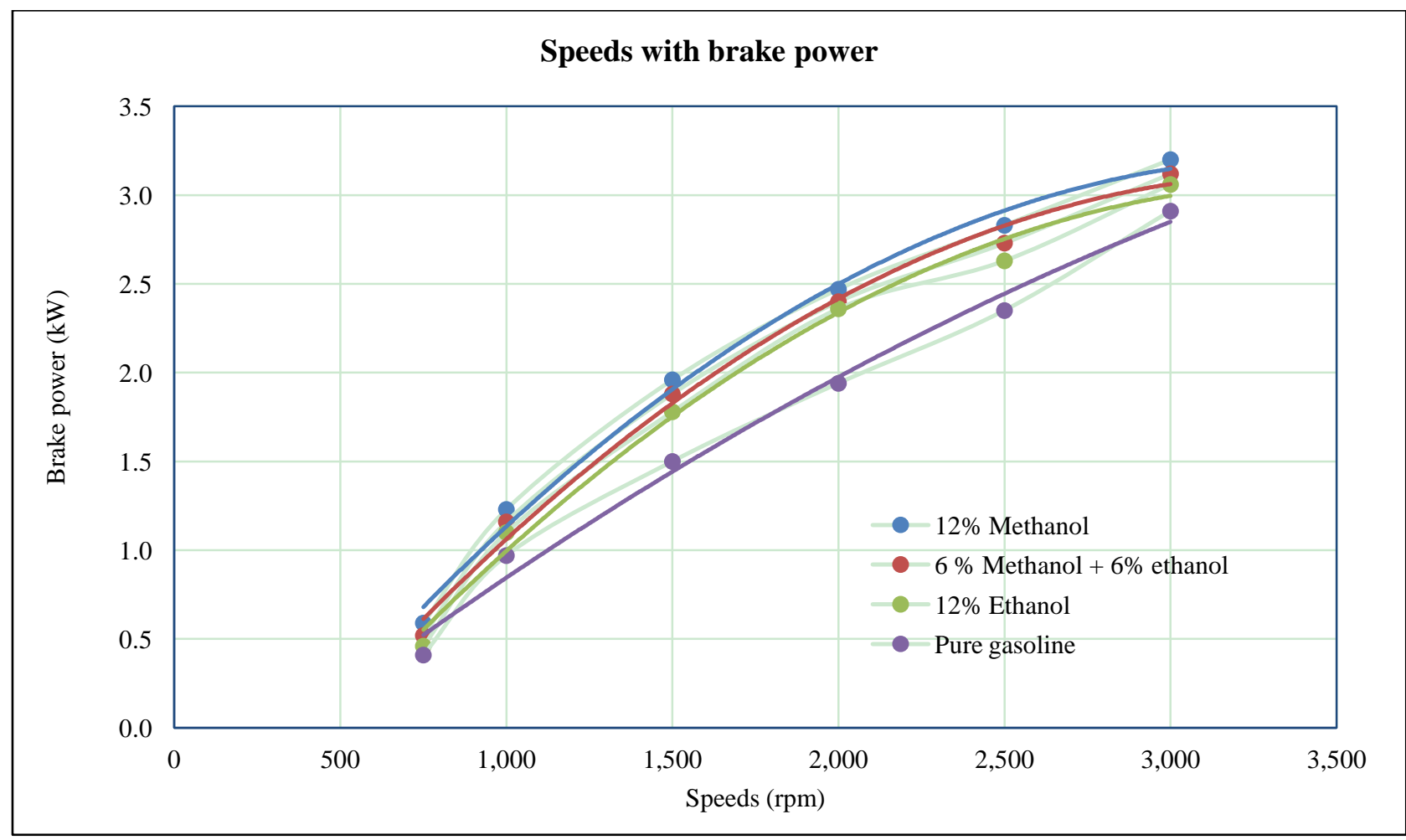

Fig. 2 Brake power trends with engine speed for the considered fuel blends.

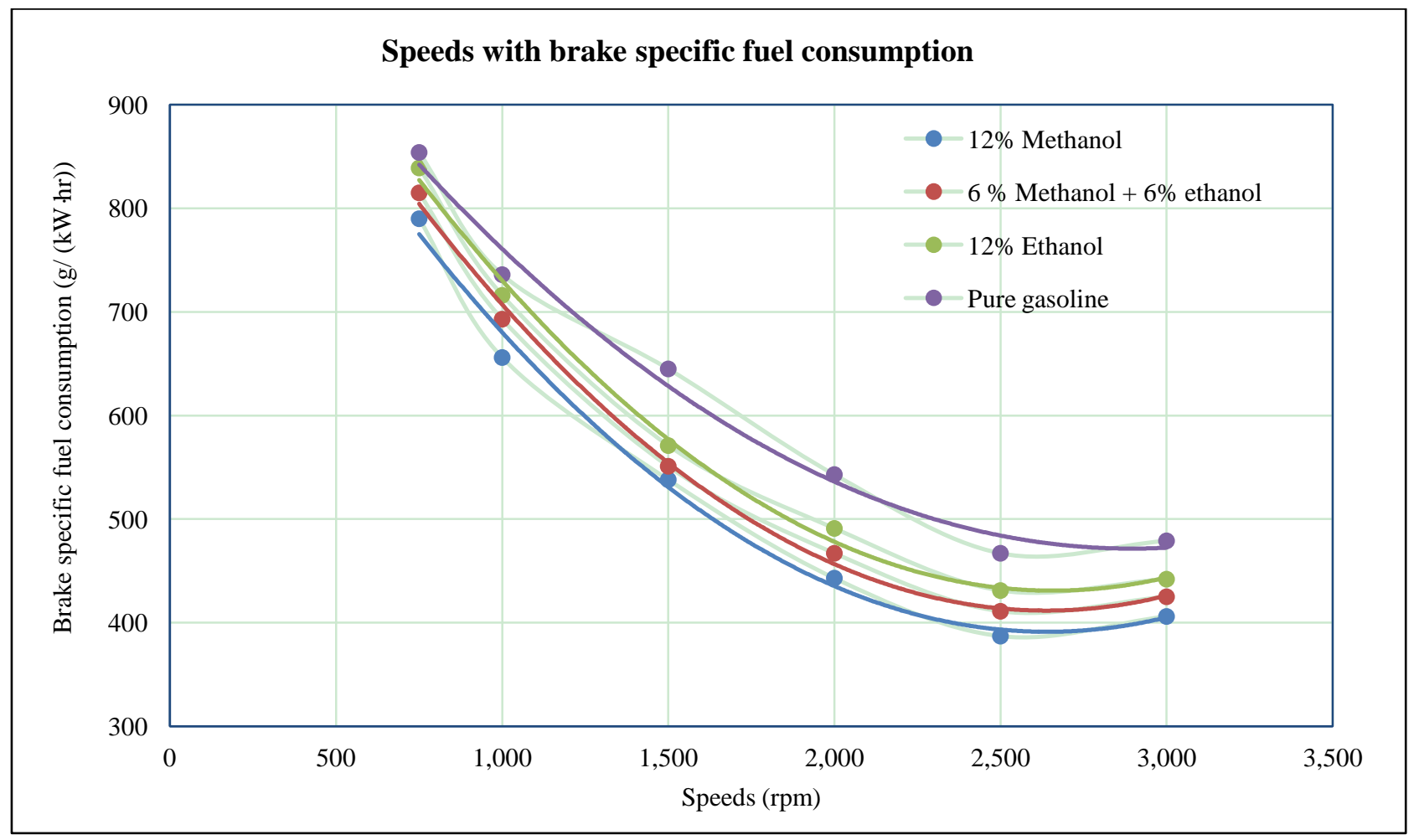

Fig. 3 BSFC trends with engine speed for the considered fuel blends. 


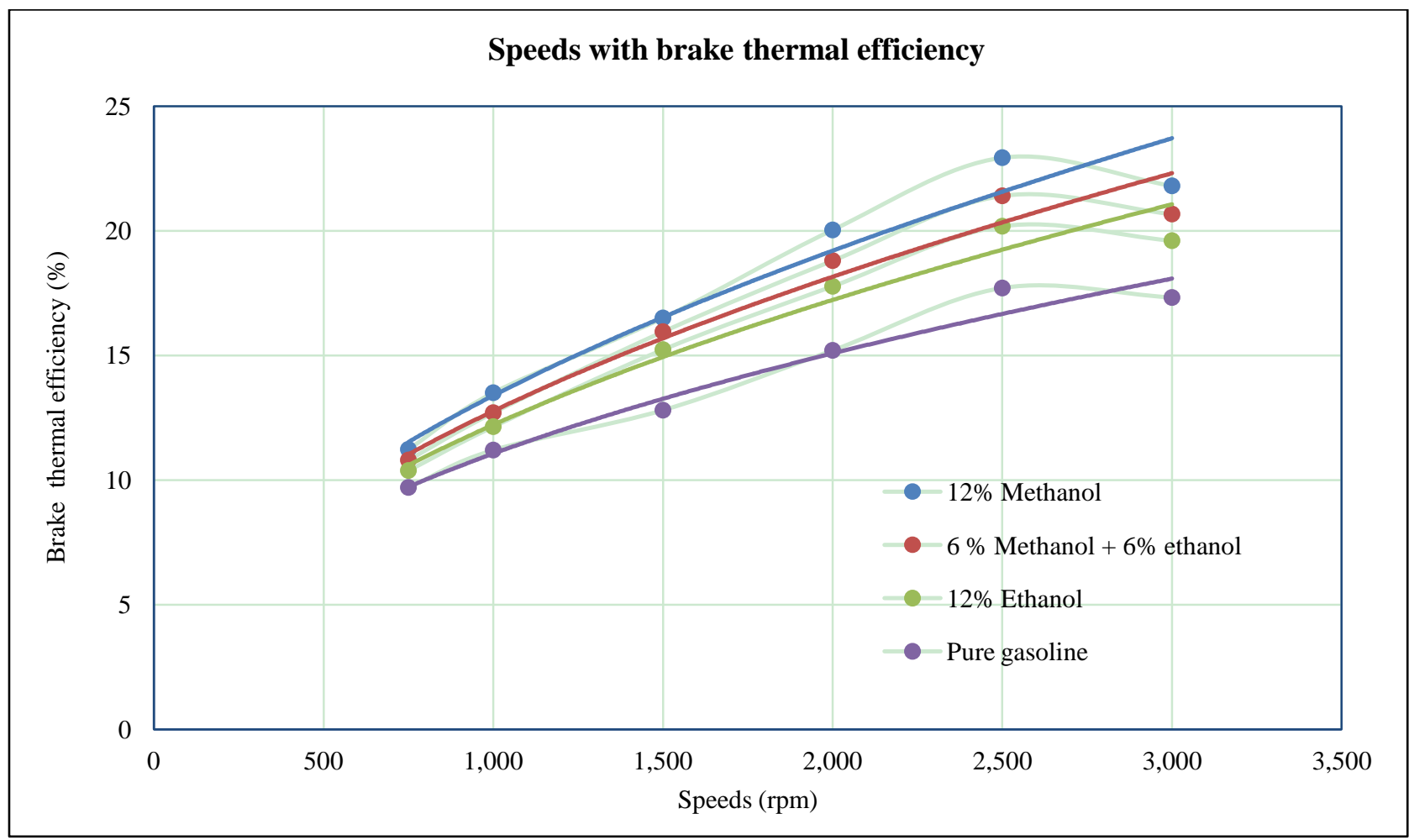

Fig. 4 Brake thermal efficiency trends with engine speed for the considered fuel blends.

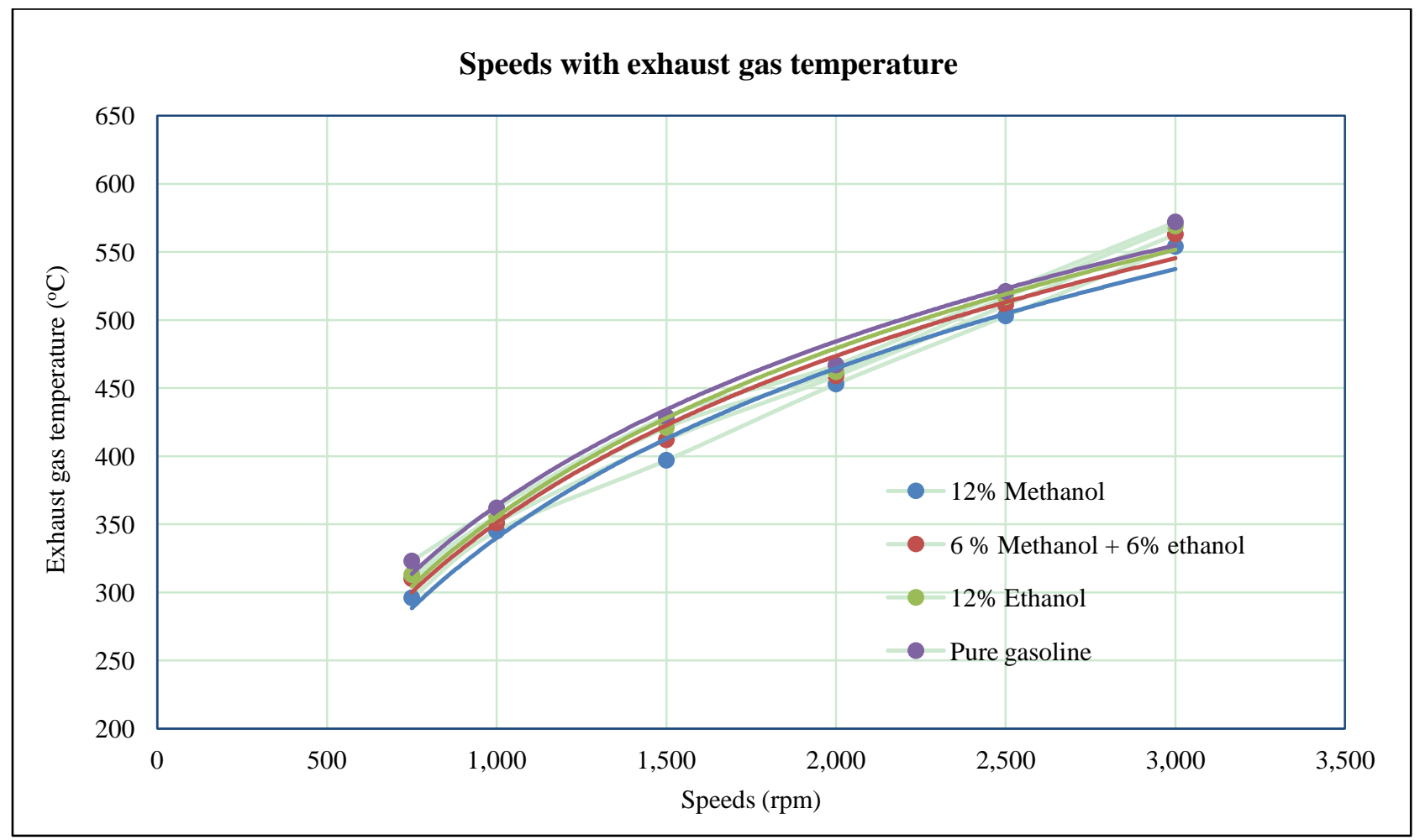

Fig. 5 Exhaust gas temperature trends with engine speed for the considered fuel blends. 
basic fuel, the lowest increase was recorded with the blend of $12 \%$ ethanol. These trends are seen when adding the alcohol fuels due the increase in the produced work. Then, the behavior of the indicated thermal power is expected to be identical since the mechanical efficiency (the ration of the brake to the indicated power) is a function of engine speed.

Since the increase in engine speed would increase the burned fuel, it is expected that the engine speed increase would result in an increase in exhaust gas temperature. This was shown in Fig. 5 where the interacted relationship between engine speed and exhaust gas temperature was depicted for the considered fuels. At 2,000 rpm and compared with the neat gasoline fuel, the operations with the $88 \%$ gasoline- $6 \%$ methanol-6\% ethanol, $88 \%$ gasoline- $12 \%$ methanol and $88 \%$ gasoline-12\% ethanol blends showed decreases in exhaust gas temperatures of $1.97 \%$, $3.3 \%$, and $1.7 \%$, respectively. These trends can be assigned to the following reasons, the basic gasoline fuel has the highest combustion period which is the main parameter in the exhaust gas temperature. Therefore, the shorter combustion periods of the alcohol fuels resulted in reducing the exhaust gas temperature which is preferred to reduce the harmful exhaust emissions.

\section{Conclusions}

In this study, engine performance from different blended fuels in types (ethanol, methanol and gasoline) has been investigated experimentally. The test results indicated that:

(1) Alcohol additives (methanol and ethanol) showed a substantial enhancement in the performance of the gasoline engine.

(2) A superior performance is recorded for the blends in the order: $88 \%$ gasoline- $12 \%$ methanol, $88 \%$ gasoline-6\% methanol-6\% ethanol, and $88 \%$ gasoline- $12 \%$ ethanol compared with the basic engine.

(3) Taking the advantages of rising up the ON, the addition of methanol and ethanol to the gasoline fuel would enable running the engine with higher compression rations.

\section{References}

[1] Kamil, M., and Rahman, M. M. 2015. "Performance Prediction of Spark-Ignition Engine Running on Gasoline-Hydrogen and Methane-Hydrogen Blends." Applied Energy 158 (November): 556-67.

[2] Entenberg, R. D., and Menard, A. L. 1966. "Future Octane Number Requirements for Future Market Demand." Journal of Marketing 30 (1): 28-32.

[3] Agarwal, A. K. 2007. "Biofuels (Alcohols and Biodiesel) Applications as Fuels for Internal Combustion Engines." Progress in Energy and Combustion Science 33 (3): 233-71.

[4] Marin, A., and Kodjak, D. 1998. Relative Cancer Risk of Reformulated Gasoline and Conventional Gasoline Sold in the Northeast. Boston: Northeast States for Coordinated Air Use Management (NESCAUM).

[5] Kourtidisa, K. A., Ziomasa, I., Zerefosa, C., Kosmidisa, E., Symeonidisa, P., Christophilopoulosa, E., Karathanassisa, S., and Mploutsosb, A. 2002. "Benzene, Toluene, Ozone, $\mathrm{NO}_{2}$ and $\mathrm{SO}_{2}$ Measurements in an Urban Street Canyon in Thessaloniki, Greece." Atmospheric Environment 36 (34): 5355-64.

[6] Grimshaw, P., 1995. The Gothenburg Bible and Volvo Performance Handbook, 2nd Edition, Volvo Cars Technical Books, Sweden.

[7] Koç, M., Sekmen, Y., Topgu, T., and Yu, H. S. 2009. "The Effects of Ethanol Unleaded Gasoline Blends on Engine Performance and Exhaust Emissions in a Spark-Ignition Engine." Renewable Energy 34 (10): 2101-6.

[8] Surisetty, V. R., Dalai, A. K., and Kozinski, J. 2011. "Alcohols as Alternative Fuels: An Overview." Applied Catalysis A: General 404 (1-2): 1-11.

[9] Elfasakhany, A. 2015. "Investigations on the Effects of Ethanol-Methanol-Gasoline Blends in a Spark-Ignition Engine: Performance and Emissions Analysis." Engineering Science and Technology, an International Journal 18 (4): 713-9.

[10] Jiang, Z. Y., Wu, H., Xu, S. W., and Huang, S. F. 2002. "Enzymatic Conversion of Carbon Dioxide to Methanol by Dehydrogenases Encapsulated in Sol-Gel Matrix." Fuel Chemistry Division Preprints 47 (1): 306.

[11] Elfasakhany, A. 2013. "Investigation on Performance and Emissions Characteristics of an Internal Combustion Engine Fuelled with Petroleum Gasoline and a Hybrid Methanol-Gasoline Fuel." International Journal of Engineering \& Technology 13 (5): 24-43.

[12] Elfasakhany, A. 2014. "The Effects of Ethanol-Gasoline 
Blends on Performance and Exhaust Emission Characteristics of Spark Ignition Engines.” International Journal of Automotive Engineering 4 (1): 608-20.

[13] Akutsu, Y., Toyoda, F., Tomita, K., Yoshizawa, F., Tamura, M., and Yoshida, T. "Effect of Exhaust from Alcohol Fuel on Ozone Formation in the Atmosphere." Atmospheric Environment. Part A. General Topics 25 (7): 1383-9.

[14] Ozsezen, A. N., and Canakci, M. 2011. "Performance and Combustion Characteristics of Alcohol Gasoline Blends at Wide-Open Throttle.” Energy 36 (5): 2747-52.

[15] Pischinger, F. F. 1983. "Alcohol Fuels for Automotive Engines." 11th World Petroleum Congress 6 (3): 216-26.

[16] Bata, R. M., Elord, A. C., and Rice, R. W. 1989. "Emissions from IC Engines Fueled with Alcohol-Gasoline Blends: A Literature Review." Journal of Engineering for Gas Turbines and Power 111 (3): 424-31.

[17] Al-Hasan, M. 2003. "Effect of Ethanol-Unleaded Gasoline Blends on Engine Performance and Exhaust Emissions." Energy Conversion and Management 44 (9): 1547-61.

[18] Alexandrian, M., and Schwalm, M. 1992. "Comparison of Ethanol and Gasoline as Automotive Fuels." In Proceedings of the ASME Winter Annual Meeting, 542-9.

[19] Yucesu, H. S., Topgul, T., Cinar, C., and Okur, M. 2006. "Effect of Ethanol-Gasoline Blends on Engine Performance and Exhaust Emissions in Different Compression Ratios." Applied Thermal Engineering 26 (17-18): 2272-8.

[20] Topgul, T., Yucesu, H. S., and Cýnar, C. 2004. "The Experimental Investigation of the Effect of Ethanol-Gasoline Blends on Engine Performance in Different Compression Ratios on a Spark Ignition Engine." Presented at the 8th International Combustion Symposium, Ankara, Turkey.

[21] Rice, R. W., Sanyal, A. K., Elrod, A. C., and Bata, R. M. 1991. "Exhaust Gas Emissions of Butanol, Ethanol, and Methanol-Gasoline Blends." Journal of Engineering for Gas Turbines and Power 113 (3): 377-81.

[22] Palmer, F. H. 1986. Vehicle Performance of Gasoline
Containing Oxygenates. Northgate Avenue: Mechanical Engineering Publications Limited.

[23] Hsieh, W. D., Chen, R. H., Wu, T., and Lin, T. 2002. "Engine Performance and Pollutant Emission of an SI Engine Using Ethanol-Gasoline Blended Fuels." Atmospheric Environment 36 (3): 403-10.

[24] Wu, W., Chen, R. H., Pu, J. Y., and Lin, T. H. 2004. "The Influence of Air-Fuel Ratio on Engine Performance and Pollutant Emission of an SI Engine Using Ethanol-Gasoline Blended Fuels." Atmospheric Environment 38 (40): 7093-100.

[25] He, B. Q., Wang, J. X., Hao, J. M., Yan, X. G., and Xiao, J. H. 2003. "A Study on Emission Characteristics of an EFI Engine with Ethanol Blended Gasoline Fuels." Atmospheric Environment 37 (7): 949-57.

[26] Gravalos, I., Moshou, D., Gialamas, T., Xyradakis, P., Kateris, D., and Tsiropoulos, Z. 2001. "Performance and Emission Characteristics of Spark Ignition Engine Fuelled with Ethanol and Methanol Gasoline Blended Fuels." In Alternative Fuel, edited by Manzanera, M. New York: InTech.

[27] Pikunas, A., Pukalskas, S., and Grabys, J. 2003. "Influence of Composition of Gasoline-Ethanol Blends on Parameters of Internal Combustion Engines." Journal of KONES Internal Combustion Engines 10 (3-4): 179-88.

[28] Abu-Zaid, M., Badran, O., and Yamin, J. 2004. "Effect of Methanol Addition on the Performance of Spark Ignition Engines." Energy Fuels 18 (2): 312-5.

[29] Mallikarjun1, M. V., and Mamilla. V. R. 2009. "Experimental Study of Exhaust Emissions \& Performance Analysis of Multi Cylinder S.I. Engine When Methanol Used as an Additive." International Journal of Electronic Engineering Research 1 (3): 201-12.

[30] Shenghua, L., Clemente, E. R. C., Tiegang, H., and Yanjv, W. 2007. "Study of Spark Ignition Engine Fueled with Methanol/Gasoline Fuel Blends." Applied Thermal Engineering 27 (11-12): 1904-10. 